\begin{tabular}{|c|l|}
\hline Title & $\begin{array}{l}\text { Two species of the genus A cinetospora (Ectocarpales, Phaeophy ceae) from Japan: A. filamentosa comb. nov and A. } \\
\text { asiatica sp nov. }\end{array}$ \\
\hline Author(s) & $\begin{array}{l}\text { Y aegashi, Kousuke; Y amagishi, Y ukimasa; U wai, Shinya; A be, T suy oshi; Santianez, Wilfred John Eria; Kogame, } \\
\text { Kazuhiro }\end{array}$ \\
\hline Citation & $\begin{array}{l}\text { Botanica marina, 58(5), 331-343 } \\
\text { https://doi.org/10.1515/bot-2015-0051 }\end{array}$ \\
\hline Issue Date & 2015-10 \\
\hline Doc URL & http://hdl.handle.net/2115/62730 \\
\hline Type & article \\
\hline File Information & bot-2015-0051.pdf \\
\hline
\end{tabular}

Instructions for use 


\section{Two species of the genus Acinetospora (Ectocarpales, Phaeophyceae) from Japan: A. filamentosa comb. nov. and $A$. asiatica sp. nov.}

DOI 10.1515/bot-2015-0051

Received 27 June, 2015; accepted 1 September, 2015; online first 22 September, 2015

\begin{abstract}
The brown algal genus Acinetospora is characterised by sparsely branched uniseriate filaments, scattered meristematic zones, short laterals ("crampons") and scattered reproductive organs. The morphology and life history of the generitype $A$. crinita have been studied repeatedly, and accounts of the species' highly varied reproductive patterns were assumed to be due to the presence of multiple taxa that were reported under this name. Herein, we attempt to contribute to the taxonomy of the genus by conducting morphological and culture studies on 33 Acinetospora samples collected from Japan. We recognised two Acinetospora species and propose to name them $A$. filamentosa comb. nov. and $A$. asiatica sp. nov. These two species are distinguished from $A$. crinita by the absence of monosporangia and plurilocular acinetosporangia/megasporangia. Acinetospora filamentosa and $A$. asiatica have similar vegetative morphologies but possess different reproductive patterns. The former forms unilocular sporangia on erect filaments and both unilocular sporangia and plurilocular zoidangia on prostrate filaments, while the latter forms plurilocular zoidangia only on both erect and prostrate filaments. Molecular analyses based on $r b c \mathrm{~L}$ and $c o x 1$ genes supported independence of these species.
\end{abstract}

\footnotetext{
*Corresponding author: Kazuhiro Kogame, Faculty of Science, Department of Biological Sciences, Hokkaido University, Sapporo 060-0810, Japan, e-mail: kogame@sci.hokudai.ac.jp Kousuke Yaegashi and Wilfred John Eria Santiañez: Department of Natural History Sciences, Graduate School of Science, Hokkaido University, Sapporo 060-0810, Japan

Yukimasa Yamagishi: Faculty of Life Science and Biotechnology, Fukuyama University, Fukuyama 729-0292, Japan

Shinya Uwai: Faculty of Science, Department of Environmental Science, Niigata University, Niigata 950-2181, Japan Tsuyoshi Abe: The Hokkaido University Museum, Hokkaido University, Sapporo 060-0810, Japan
}

Keywords: Acinetospora asiatica sp. nov.; Acinetospora filamentosa comb. nov.; cox1; Ectocarpales; rbcL.

\section{Introduction}

Acinetospora (Acinetosporaceae, Ectocarpales) is a genus of filamentous brown algae whose sparsely branched uniseriate filaments form entangled tufts on other seaweeds. This genus was established by Bornet (1891) for plants with plurilocular sporangia (acinetosporangia) that produce large non-motile cells (acinetospores). Later, additional characters were used to circumscribe the genus, which include possessing monosporangia that produce a non-motile spore, scattered meristematic zones and straight to curved short laterals called "crampons" (Sauvageau 1895, 1899, Cardinal 1964, Kim and Lee 1994, Pedersen and Kristiansen 2001). The generitype A. pusilla (Griffiths ex Harvey) De Toni (1895), which was originally described from the British Isles (Harvey 1841), is currently considered as a taxonomic synonym of $A$. crinita (Carmichael in Harvey) Sauvageau (1899) (Pedersen and Kristiansen 2001). Only two species are currently recognised in this genus: A. crinita (type locality: British Isles, Harvey 1833) and A. nicholsoniae Hollenberg (1971) (type locality: Santa Catalina Is., California).

Acinetospora crinita is found in warm to cold coastal marine waters, and there are numerous reports on its morphology and life history around the world, such as in Europe (Pedersen and Kristiansen 2001, and included references), the east coast of the United States (Amsler 1984), East Asia (Tanaka and Chihara 1977, Kim and Lee 1994, Kim 2010) and Australia (Clayton 1974, Womersley 1987). This species exhibited different life history patterns among different culture strains and populations (Pedersen and Kristiansen 2001, and included references). For example, Kornmann (1953) reported plurilocular acinetosporangia, unilocular sporangia and plurilocular zoidangia with small and large loculi in German isolates, while Müller (1986) found monosporangia and unilocular 
sporangia in an Italian isolate. Meanwhile, Pedersen and Kristiansen (2001) observed that their Danish strain of $A$. crinita formed both monosporangia and plurilocular zoidangia with small loculi or large loculi, but their French strain formed only plurilocular zoidangia (megasporangia) with very large loculi. Pedersen and Kristiansen (2001) also pointed out that there is no clear distinction between plurilocular acinetosporangia and megasporangia before liberation of spores/zoids. In contrast to European isolates, Japanese A. crinita produced plurilocular or unilocular sporangia but was not observed to have monosporangia or plurilocular acinetosporangia/megasporangia (Kurogi 1950, Tanaka and Chihara 1977, Kitayama 1996).

Considering these highly variable reproductive patterns, previous workers on $A$. crinita suggested that plants under this name possibly include more than one species (Müller 1986, Pedersen and Kristiansen 2001). However, detailed taxonomic studies are limited and molecular data that can be used to investigate the relationships in Acinetospora remain scarce. Herein, we report on morphological, culture and molecular phylogenetic studies to investigate the diversity and relationships of Acinetospora from Japan.

\section{Materials and methods}

Samples of Acinetospora were collected from 11 localities in Japan (Figure 1, Table 1). From the collected samples, pressed specimens were made as voucher herbarium specimens, and unialgal isolates were established by transferring a short fragment of a thallus filament into individual wells of a 48-well plate containing PESI medium (Tatewaki 1966). Four unialgal isolates were established from emerging algae in crude cultures of other seaweeds. Voucher specimens are deposited in the Herbarium of the Faculty of Science, Hokkaido University (SAP112484-112510). Cultures were inoculated in plastic Petri dishes (circular, $90 \mathrm{~mm}$ diameter $\times 20 \mathrm{~mm}$ depth) containing PESI medium. Culture conditions used were $5^{\circ} \mathrm{C} \mathrm{SD}$ (short day, 8:16 h light:dark regime), $10^{\circ} \mathrm{C} \mathrm{SD}, 10^{\circ} \mathrm{C}$ LD (long day, $16: 8 \mathrm{~h}$ light:dark regime), $15^{\circ} \mathrm{C} \mathrm{SD}, 15^{\circ} \mathrm{C} \mathrm{LD}, 20^{\circ} \mathrm{C} \mathrm{SD}, 20^{\circ} \mathrm{C} \mathrm{LD}$ and $25^{\circ} \mathrm{C} \mathrm{LD}$, under $30-50 \mu \mathrm{mol} \mathrm{m}^{-2} \mathrm{~s}^{-1}$.

Total genomic DNA was extracted from cultured thalli and purified as previously described by Kogame et al. (1999). The purified DNA was used as template DNA for PCR to amplify the $r b c \mathrm{~L}$ and $c o x 1$ genes. Primers for PCR and sequencing in $r b c \mathrm{~L}$ gene were PRB-F0, PRB-F2, PRB-F3, PRB-R1A, PRB-R2, PRBR3A and RSPR (Kogame et al. 1999) as well as those designed in the present study (Table 2). The primer pair used for cox1 was GazF2 and GazR2 (Lane

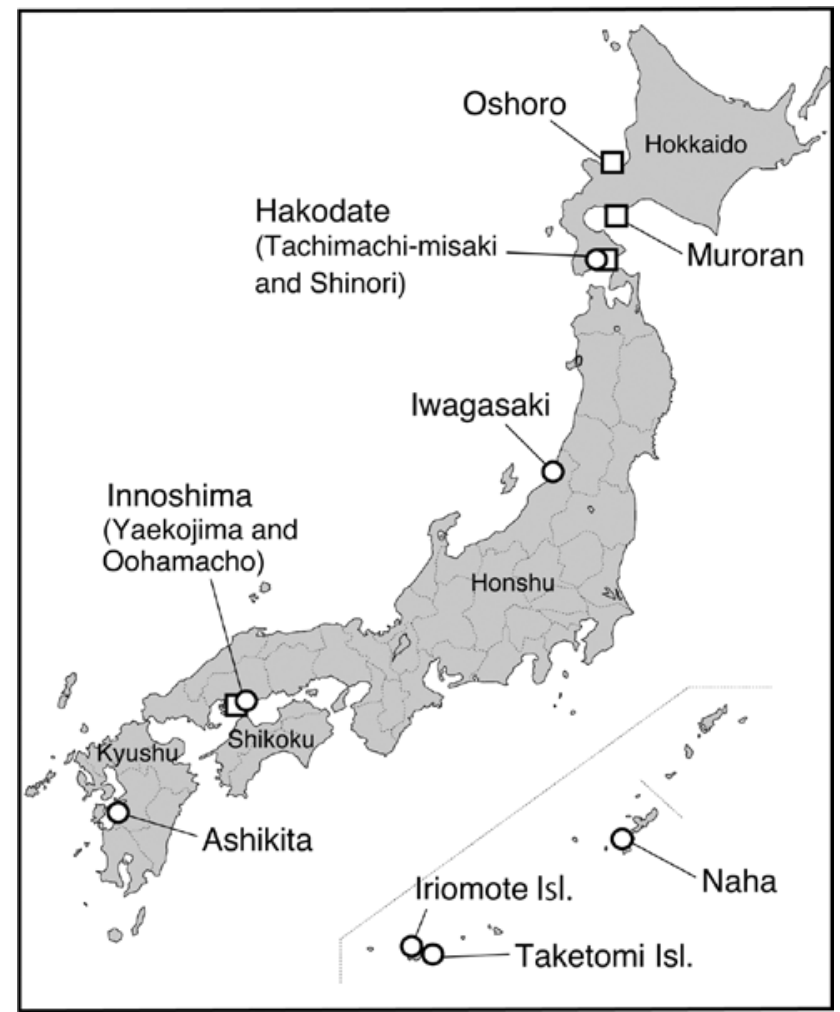

Figure 1: Collection localities in Japan for samples of Acinetospora used for phylogenetic analyses in this study. Circles, A. filamentosa; squares, $A$. asiatica.

et al. 2007). PCR was performed using TaKaRa Ex Taq DNA Polymerase (TAKARA Bio Inc., Otsu, Japan). Amplification conditions consisted of $1 \mathrm{~min}$ at $94^{\circ} \mathrm{C}$ for denaturation, followed by $40-50$ cycles of $30 \mathrm{~s}$ at $94^{\circ} \mathrm{C}, 30 \mathrm{~s}$ at $52^{\circ} \mathrm{C}$ and $30 \mathrm{~s}$ at $72^{\circ} \mathrm{C}$, with a final extension of $5 \mathrm{~min}$ at $72^{\circ} \mathrm{C}$. PCR was performed with a GeneAmp PCR System 9600 or 9700 (PE Applied Biosystems, Foster City, USA). PCR products were precipitated using PEG (polyethylene glycol=6000, Nakalai Tesque, Kyoto, Japan) and were directly sequenced using an ABI Prism BigDye Terminator Cycle Sequencing Ready Reaction Kit v. 1.1 (PE Applied Biosystems) and an ABI Prism 3130 or 3730 Genetic Analyzer (PE Applied Biosystems), following the manufacturer's protocols.

The $r b c \mathrm{~L}$ sequences produced were aligned with previously published sequences of the Ectocarpales, adding two species of Asterocladon as outgroup taxa (Peters and Ramírez 2001, Silberfeld et al. 2011). The cox1 sequences produced were aligned with published sequences of the Acinetospora cluster (Peters et al. 2015), which included a European A. crinita. Pairwise sequence differences (p-distances) were calculated in MEGA5.2 (Tamura et al. 2011). Phylogenetic analyses of $r b c \mathrm{~L}$ were performed using Bayesian inference (BI) and maximum likelihood (ML) analyses as implemented in MrBayes 3.2* (Ronquist and 


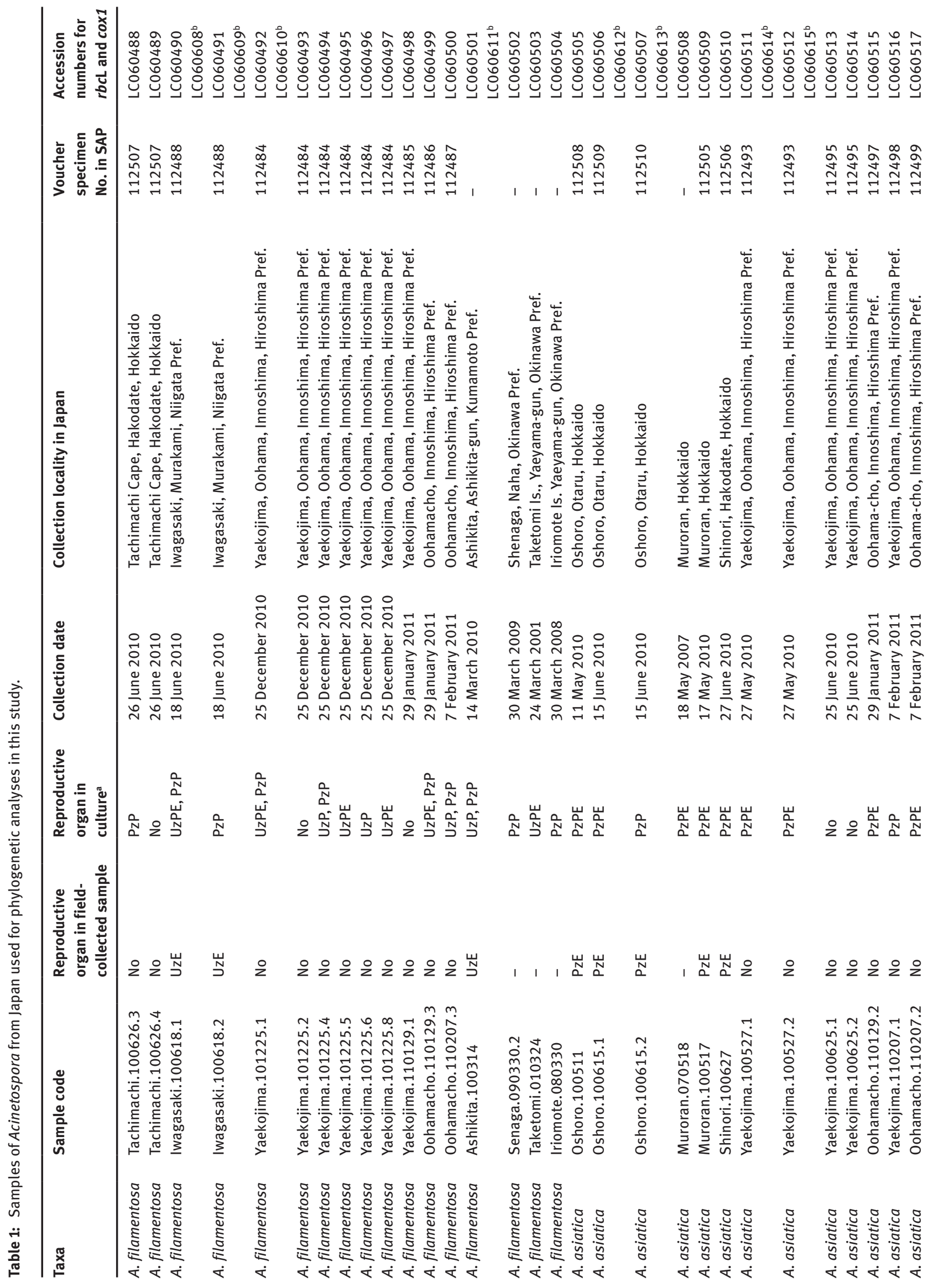


Table 2: PCR and sequencing primers designed for $r b c L$ gene in this study.

\begin{tabular}{ll}
\hline Primer code $^{\mathbf{a}}$ & Sequence \\
\hline PRB-ac1 (F) & 5'-ACGTTTAGAAGATATGAGAA-3' $^{\prime}$ \\
PRB-ac3 (F) & $5^{\prime}$-GGCAAGAAAGTACGAAATGA-3' \\
PRB-ac5 (F) & $5^{\prime}$-TCACCCAGATGGTATTCAAT-3' \\
PRB-ac2 (R) & $5^{\prime}$-CCTTTAACCATTAAAGGATC-3' \\
PRB-ac4 (R) & $5^{\prime}$-TCTTTCCATAAATCTAAAGC-3' \\
\hline
\end{tabular}

a(F): Forward, (R): reverse.

Huelsenbeck 2003) and MEGA5.2, respectively. BI analyses used a GTR $+\mathrm{I}+\mathrm{G}$ model selected by hLRT and AIC in MrModeltest 2.3 (Nylander 2004) and were performed with four runs of Markov chains with 2 million generations and sampling every 100 generations. The first $25 \%$ of trees were discarded as burn-in. ML trees were inferred by the nearestneighbour-interchange method with a TN93+G+I model, which was selected as the best-fitting model by the BIC in MEGA5.2. In the phylogenetic analyses of cox1, NeighbourJoining (NJ) trees were inferred using Tamura-Nei distance (Tamura and Nei 1993) in MEGA5.2. Bootstrap analyses (Felsenstein 1985) were performed with 500 and 1000 bootstrap pseudoreplicates for ML and NJ analyses, respectively.

\section{Results}

\section{Acinetospora filamentosa (Noda) Yaegashi, Uwai et Kogame comb. nov. (Figure 2A-G)}

\section{Basionym}

Ectocarpus filamentosus Noda 1970. Sci. Rep. Niigata Univ., Ser.D 7: 27.

\section{Synonym}

Ectocarpus ugoensis Konno in Konno et Noda 1974. Sci. Rep. Niigata Univ., Ser. D 11: 80.

Plants are uniseriate, branched filaments, forming entangled tufts to $10 \mathrm{~cm}$ or more in length attached to rocks and other seaweeds (e.g. Sargassum spp.). Erect filaments are irregularly and sparsely branched at wide to right angles and form short, straight to curved "crampons". Meristematic zones are scattered, consisting of short cells. Cells of erect filaments are $20-80 \mu \mathrm{m}$ in length and $18-28 \mu \mathrm{m}$ in width, containing many discoid chloroplasts with pyrenoids. Phaeophycean hairs are found laterally 
or terminally on erect filaments. Unilocular sporangia are spherical to oval, $25-55 \mu \mathrm{m}$ in length and $25-55 \mu \mathrm{m}$ in width, sessile or with a pedicel, and are formed on erect filaments.

In samples collected from Iwagasaki, Niigata Pref. and Ashikita, Kumamoto Pref., unilocular sporangia and phaeophycean hairs were observed, and crampons were rare (Figure $2 \mathrm{~A}-\mathrm{C}$ ). In contrast, in samples collected from Tachimachi-misaki, Hokkaido and Oohamacho, Hiroshima Pref., unilocular sporangia and phaeophycean hairs were not observed, and crampons were abundant. Plurilocular zoidangia were not found in field-collected samples. Plants were collected in winter from Yaekojima and Oohamacho, Innoshima, Hiroshima Pref., where monthly samplings were conducted from May 2010 to June 2011.

In cultured Acinetospora filamentosa, zoids from unilocular sporangia and plurilocular zoidangia showed similar developmental patterns. Settled zoids germinated unipolarly, forming a germ tube. Germlings developed into prostrate filaments, which produced erect filaments and phaeophycean hairs (Figure 2D, E). Prostrate filaments were irregularly branched and their cells were globular (Figure 2D, E). Young erect filaments had a terminal hair. Prostrate filaments formed plurilocular zoidangia (Figure 2D), and erect filaments also formed plurilocular zoidangia but only on the lowermost portion (Figure 2E). Erect filaments grew longer than prostrate filaments and formed scattered meristematic zones and lateral hairs. Cells of erect filaments were $25-75 \mu \mathrm{m}$ in length and $18-27 \mu \mathrm{m}$ in width. Plurilocular zoidangia were ectocarpoid, $88-135 \mu \mathrm{m}$ in length and 30-44 $\mu \mathrm{m}$ in width, and were formed with or without a pedicel (Figure 2D, E) at $10-25^{\circ} \mathrm{C}$. Settled zoids from plurilocular zoidangia were round and 8.1$11.0 \mu \mathrm{m}$ in diameter. Unilocular sporangia were spherical to oval, $52-62 \mu \mathrm{m}$ in length and 44-62 $\mu \mathrm{m}$ in width, and were formed either sessile or with a pedicel (Figure 2F, G) on prostrate and erect filaments at $10-25^{\circ} \mathrm{C}$. At $20^{\circ} \mathrm{C} \mathrm{LD}$, plants formed reproductive organs 3 weeks after germination. Plants usually produced unilocular sporangia after forming plurilocular zoidangia. In eight strains, unilocular sporangia were not observed on erect filaments while three strains did not produce any reproductive organs (Table 1).

\section{Acinetospora asiatica Yaegashi, Yamagishi et Kogame sp. nov. (Figure 3A-H)}

\section{Diagnosis}

Plants are sparsely branched uniseriate filaments up to $30 \mathrm{~cm}$ or more in length, forming entangled tufts on rocks and other seaweeds (e.g. Sargassum spp. and Scytosiphon lomentaria). Erect filaments have scattered meristematic zones consisting of short cells. Crampons are formed on erect filaments at right angles. Cells of erect filaments are 20-77 $\mu \mathrm{m}$ in length and $18-30 \mu \mathrm{m}$ in width and contain many discoid chloroplasts. Plurilocular zoidangia are ectocarpoid, $90-135 \mu \mathrm{m}$ in length and $25-40 \mu \mathrm{m}$ in width, sessile or with one- or two-celled pedicels.

\section{Holotype}

SAP112509 (Figure 3A, collected on 15 June 2010) deposited in the Herbarium (SAP), the Faculty of Science, Hokkaido University, Sapporo, Japan.

\section{Isotypes}

SAP112510-112512 deposited in SAP.

\section{Type locality}

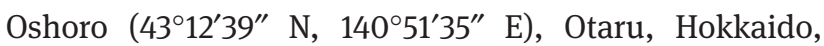
Japan.

In samples collected from Oshoro, Shinori and Muroran, Hokkaido, scattered meristematic zones, crampons and plurilocular zoidangia were observed (Figure 3B-E). Plurilocular zoidangia were not observed, however, in samples collected from Oohamacho, Innoshima, Hiroshima Pref. In Oshoro, plants were collected in May and June but were not found in April and August. In Innoshima, plants were found from January to June. Unilocular sporangia were not found in any of the samples.

In culture, zoids from plurilocular zoidangia germinated unipolarly, forming a germ tube, and developed into branched prostrate filaments (Figure 3F). Cells of prostrate filaments became globular, while cells of erect filaments were cylindrical (Figure 3F, G). Prostrate filaments formed erect filaments which tapered slightly to a pseudohair or a hair with short cells (like those of meristems) near their base and longer pale cells in the upper portion. Plurilocular zoidangia were formed on prostrate filaments and the lowermost portion of young erect filaments (Figure $3 \mathrm{G}$ ) at $10-20^{\circ} \mathrm{C}, 2-3$ weeks after germination. Erect filaments grew longer than prostrate filaments and formed plurilocular zoidangia (Figure $3 \mathrm{H}$ ) and scattered meristems. Cells of erect filaments were $23-78 \mu \mathrm{m}$ in length and 20-32 $\mu \mathrm{m}$ in width. Heterokont zoids from 

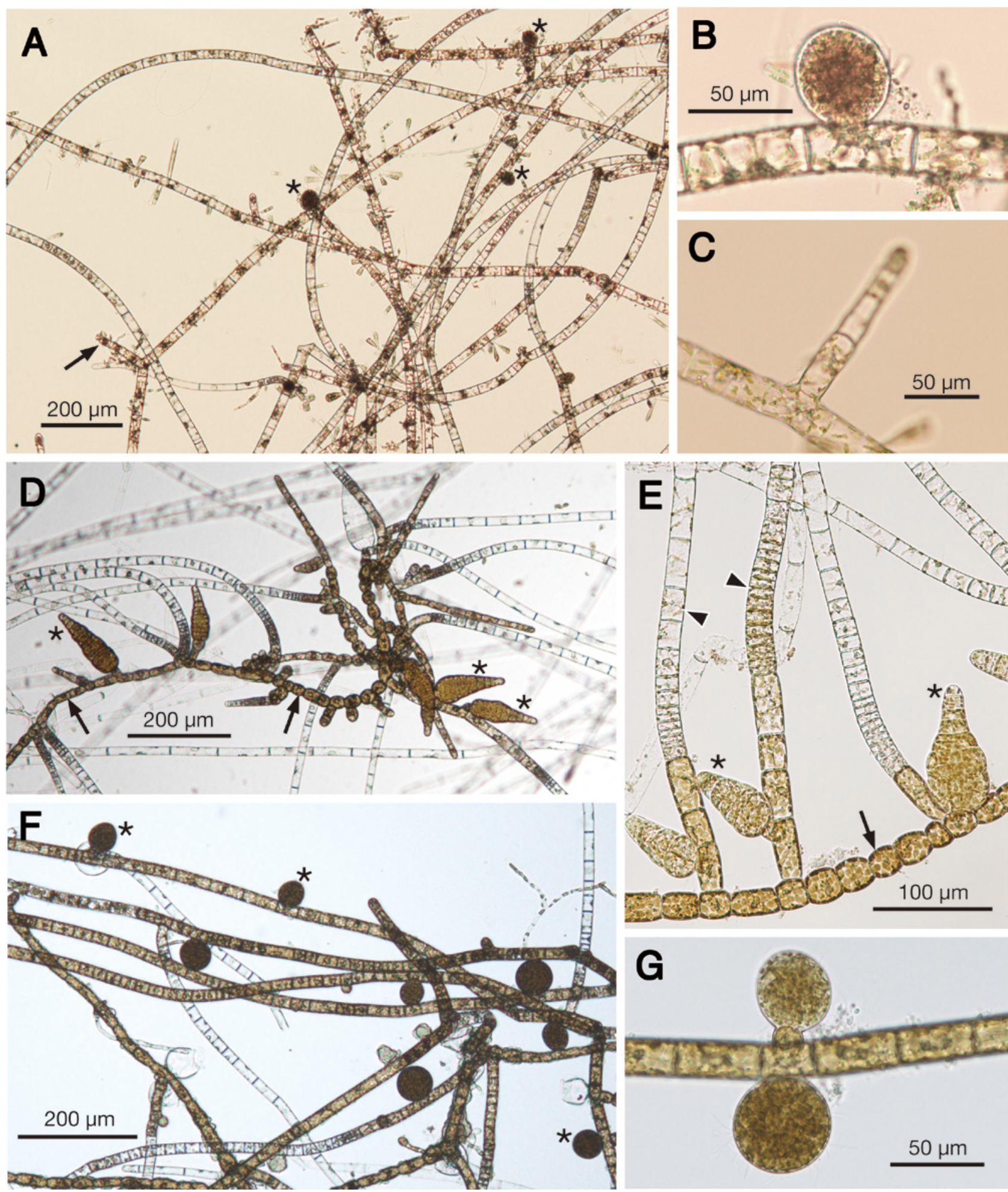

Figure 2: Acinetospora filamentosa. A-C. Field-collected thalli. A. Erect filaments with crampons (arrow) and unilocular sporangia (asterisks). B. Unilocular sporangium. C. Crampon. D-G. Cultured thalli $\left(20^{\circ} \mathrm{C}\right.$, long day). D. Young prostrate filaments (arrows) forming plurilocular zoidangia (asterisks). E. Prostrate filament (arrow), young erect filaments (arrowheads) and plurilocular zoidangia (asterisks). F. Erect filaments forming unilocular sporangia (asterisks). G. Unilocular sporangia. A-G: 18 June 2010 , Iwagasaki, Niigata Pref. 

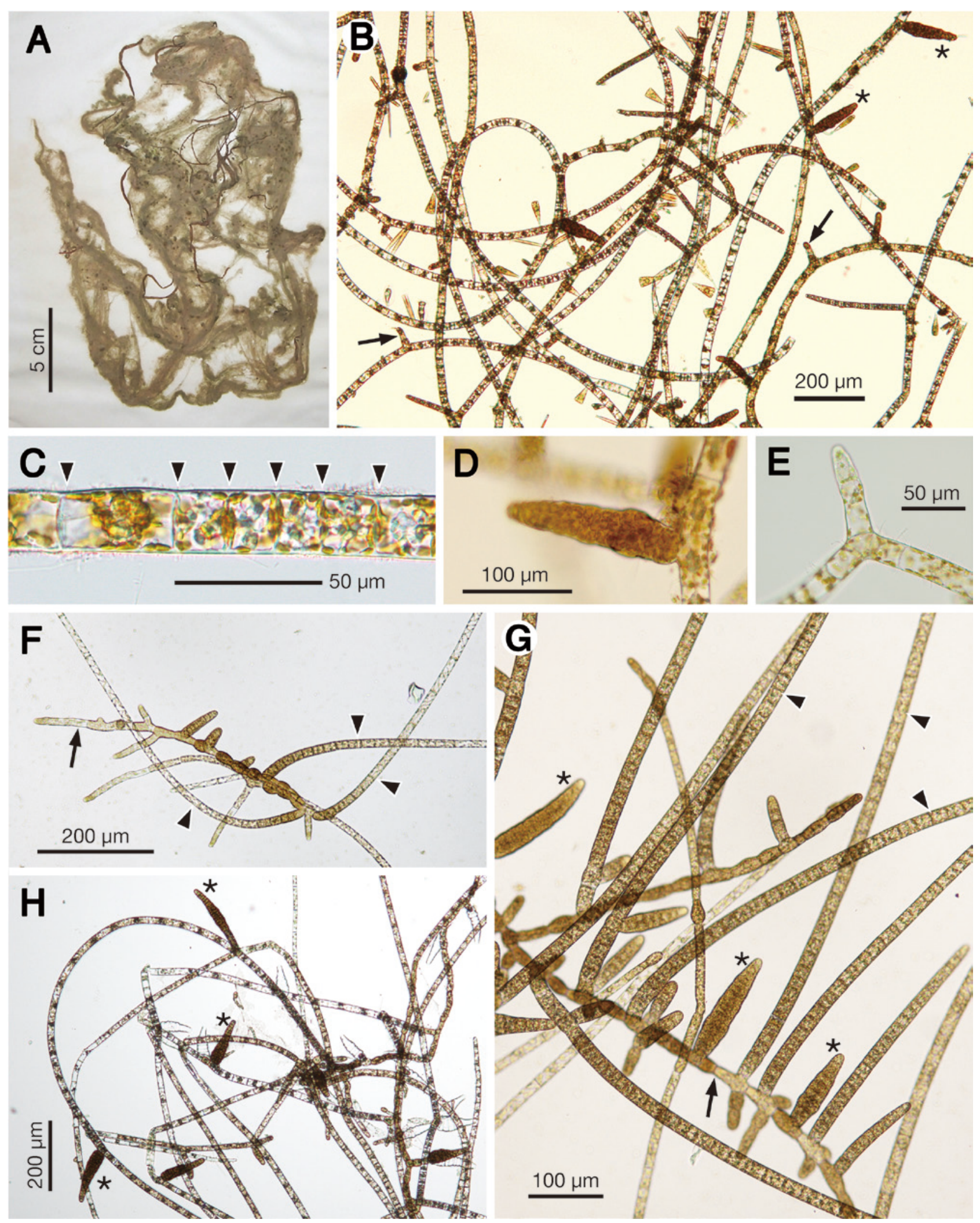

Figure 3: Acinetospora asiatica. A. Holotype (SAP112509). B-E. Field-collected thalli. B. Erect filaments forming plurilocular zoidangia (asterisks) and crampons (arrows). C. Meristem in erect filament. Arrowheads indicate boundaries between cells. D. Plurilocular zoidangium. E. Crampon. F-H. Cultured thalli $\left(20^{\circ} \mathrm{C}\right.$, long day). F. Prostrate filament (arrow) producing erect filaments (arrowheads). G. Prostrate filaments (arrow) producing erect filaments (arrowheads) and plurilocular zoidangia (asterisks). H. Erect filaments producing plurilocular zoidangia (asterisks). A, B, D-H: 15 June 2010, Oshoro, Otaru, Hokkaido. C: 27 June 2010, Shinori, Hakodate, Hokkaido. 
plurilocular zoidangia possessed an eyespot. Settled zoids from plurilocular zoidangia were round and 9.3-10.8 $\mu \mathrm{m}$ in diameter. Unilocular sporangia were not found in any culture condition. In two strains, no reproductive organs were formed at all (Table 1).

\section{Molecular analyses}

$R b c \mathrm{~L}$ sequences were determined for Acinetospora filamentosa (17 samples) and A. asiatica (16 samples). Alignment length was $1476 \mathrm{bp}$. BI and ML trees were similar and highly supported clades corresponded between the trees. Samples of A. filamentosa formed a fully supported clade, which was sister to the European sample of A. crinita (Figure 4). Samples of A. asiatica clustered with full support, and formed a clade with Feldmannia irregularis (Kützing) Hamel and Hincksia sp. The latter clade was sister to the $A$. filamentos $a-A$. crinita clade, and both clades were included in the Acinetosporaceae clade. Sequence differences (p-distances) between A. filamentosa and A. crinita were 3.0-3.3\%, those between A. asiatica and $A$. crinita were 4.6-4.7\%, and those between $A$. filamentos $a$ and $A$. asiatica were $4.0-4.6 \%$.

Partial cox 1 sequences (658 bp) were determined for A. filamentosa (four samples) and A. asiatica (four samples). In the NJ tree of $\operatorname{cox} 1$ (Figure 5), the two species of Acinetospora from Japan as well as A. crinita from Europe (Greece and Brittany, France) formed three separate clades, each with full support. The clade of $A$. asiatica consisted only of Japanese samples while the A. filamentosa clade included one unidentified sample from Greece (LM995369). Sequence differences (p-distances) were $11.3-16.3 \%$ among the three species and $<2.7 \%$ within each species.

\section{Discussion}

Acinetospora filamentosa and A. asiatica can be attributed to the genus Acinetospora based on having sparsely branched erect thalli, crampons and scattered meristematic zones. Acinetospora crinita exhibits highly varied reproductive patterns, such as producing plurilocular acinetosporangia/megasporangia, plurilocular zoidangia with large or small loculi, unilocular sporangia or monosporangia (Bornet 1891, Sauvageau 1899, Kornmann 1953, Müller 1986, Pedersen and Kristiansen 2001). In A. crinita, spores released from plurilocular acinetosporangia or megasporangia were large, approximately $20 \mu \mathrm{m}$ in diameter (Bornet 1891), and zoids released from plurilocular zoidangia with large loculi were $12 \times 12 \mu \mathrm{m}$ (Pedersen and Kristiansen 2001). Meanwhile, settled zoids from plurilocular zoidangia of Japanese Acinetospora were smaller, 8.1-11.0 $\mu \mathrm{m}$ in diameter. Further, monosporangia were not found in Japanese Acinetospora. These differences in reproductive organs (Table 3 ) suggest that A. filamentosa and A. asiatica are different species from A. crinita. The morphological differences we observed were also supported by our molecular data since these two species showed differences from European A. crinita of $3.0-4.7 \%$ in $r b c \mathrm{~L}$ and of $11.3-15.8 \%$ in cox 1 . These sequence differences are large enough for distinguishing ectocarpacean species (Siemer et al. 1998, Peters et al. 2015). Further, the Greek samples of $A$. crinita used in cox 1 analyses were observed to produce monospores (Peters, pers.com.).

Moreover, both A. filamentosa and A. asiatica differ from $A$. nicholsoniae in their vegetative morphology, as $A$. nicholsoniae has larger erect filament cells and no crampons (Hollenberg 1971). Field-collected samples of A. filamentosa were observed to possess unilocular sporangia on erect filaments and $A$. asiatica found in nature formed only plurilocular zoidangia on its erect filaments. Meanwhile, A. nicholsoniae produces both unilocular and plurilocular zoidangia on its erect filaments (Hollenberg 1971) (Table 3).

Although the vegetative morphologies of A. filamentos $a$ and $A$. asiatica are similar, they are also distinguished from each other by the type of reproductive organs they produce on erect filaments. Only unilocular sporangia were found in field-collected $A$. filamentosa while only plurilocular zoidangia were observed in A. asiatica. Our cultured A. filamentosa also formed plurilocular zoidangia on its prostrate filaments and at the basal portion of its erect filaments, but we did not find plurilocular zoidangia in field-collected samples. Our inability to find plurilocular zoidangia in field-collected $A$. filamentosa samples may be attributed to their entangled habit, which renders the basal portion of the thalli challenging to observe. In addition, we did not find $A$. asiatica with unilocular sporangia in either our field-collected or our cultured material. Separation of $A$. filamentosa and $A$. asiatica was also supported by our rbcL and cox 1 analyses in which the sequence differences between them were $4.0-4.6 \%$ and $15.2-16.3 \%$, respectively. Thus, we also describe herein a new species, A. asiatica, based on the abovementioned morphological and genetic differences.

The basionym of $A$. filamentosa is Ectocarpus filamentosus Noda (1970), which, together with E. ugoensis Konno in Konno and Noda (1974), was considered by 


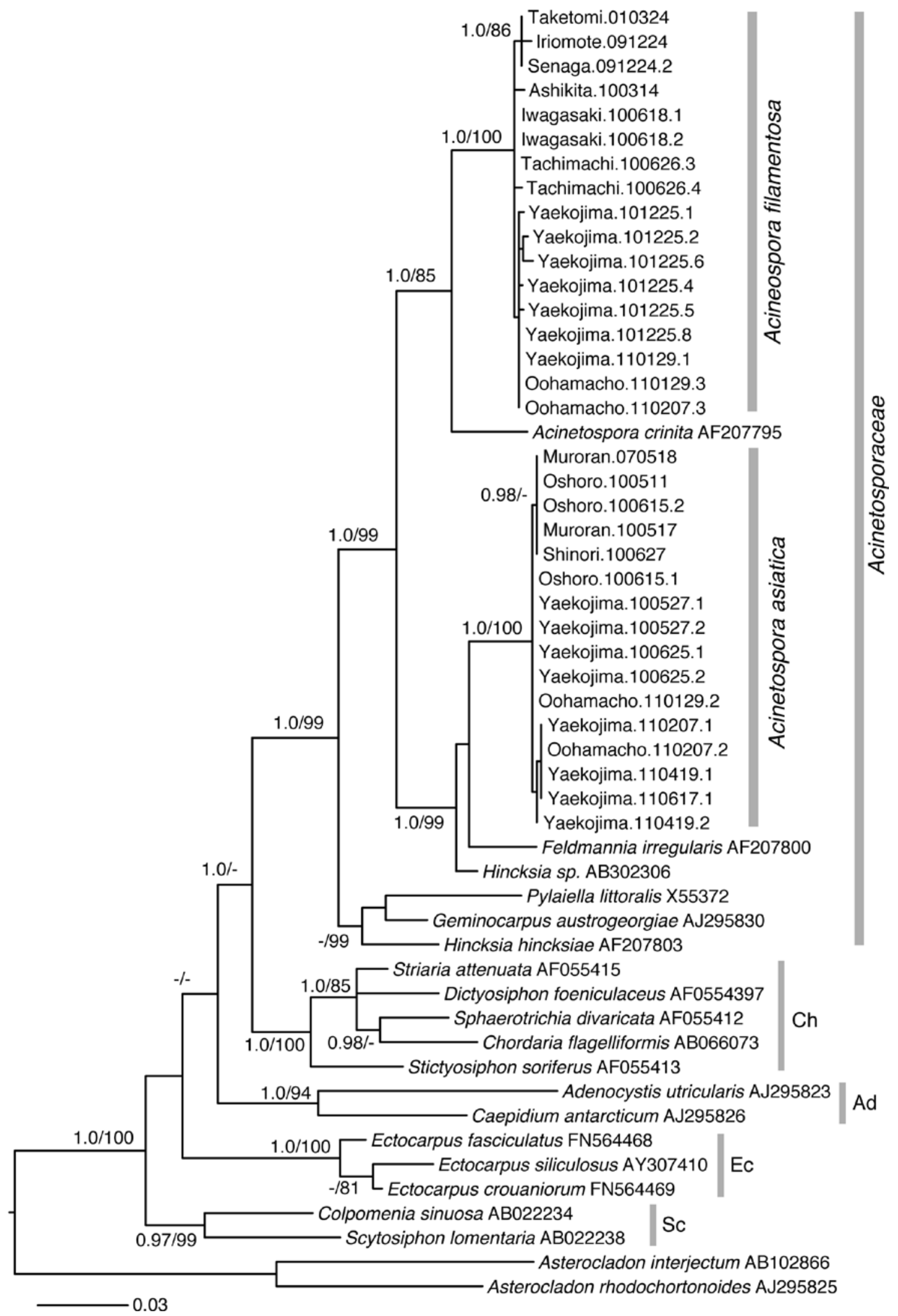

Figure 4: Bayesian tree of Ectocarpales inferred from $r b c \mathrm{~L}$ sequences. Posterior probabilities ( $>0.95)$ and bootstrap percentages ( $>80$ ) from maximum likelihood analysis are indicated near branches. "Ch" indicates Chordariaceae, "Ad” Adenocystaceae, "Ec" Ectocarpaceae and "Sc" Scytosiphonaceae. Asterocladon species are outgroup taxa. Scale bar refers to substitutions per site. 


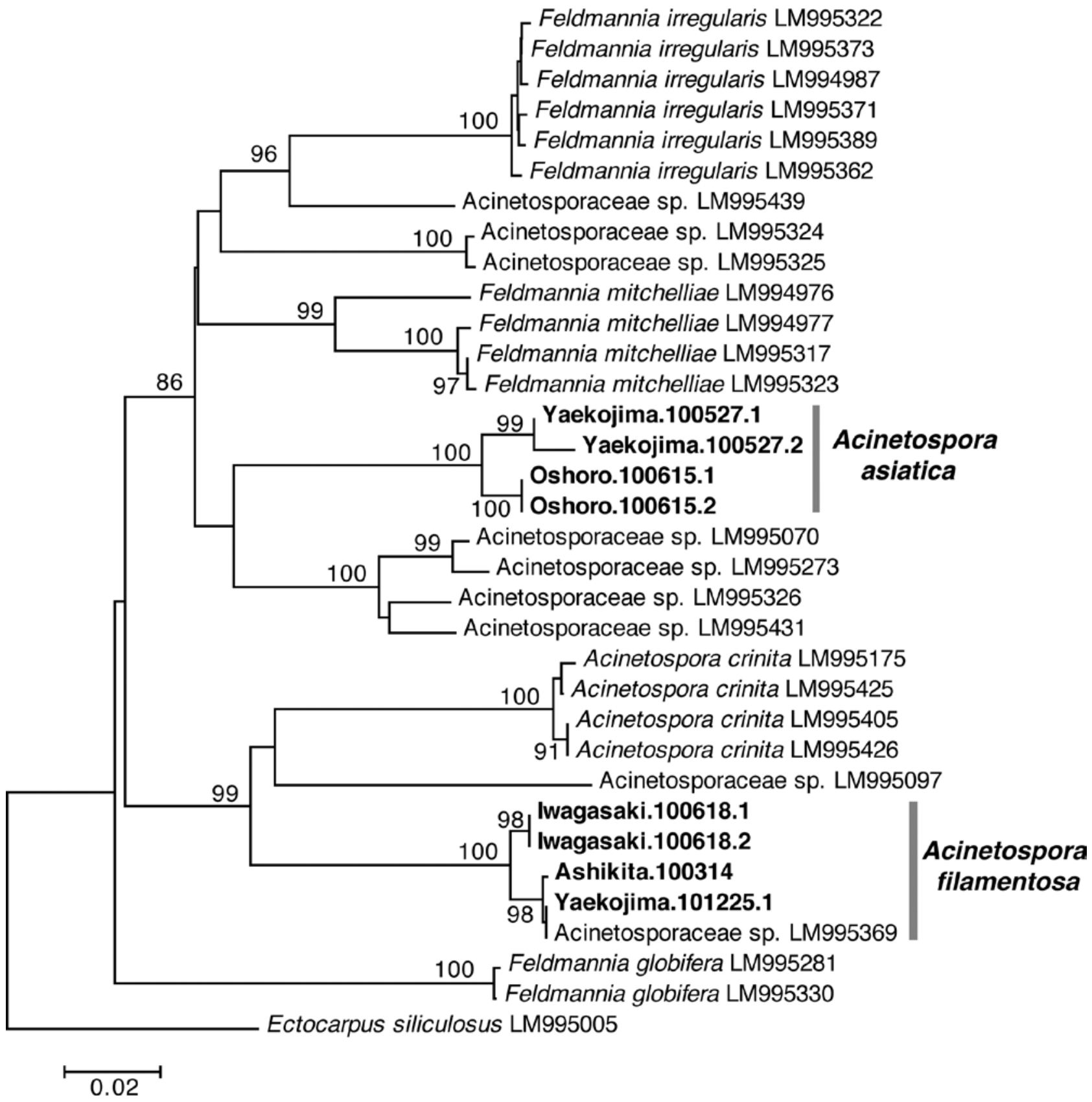

Figure 5: Neighbour-joining tree of Acinetospora and related species inferred from cox 1 sequences. Taxa in boldface were sequences determined in the present study. Bootstrap percentages $(>80)$ are indicated near branches. Ectocarpus siliculosus is an outgroup. Scale bar refers to substitutions per site.

Yoshida (1998) as a synonym of A. crinita. The type localities of E. filamentosus and E. ugoensis are Iwagasaki, Niigata Pref. and Takinoma, Akita Pref., Japan, respectively; both areas face the Sea of Japan and they are approximately $250 \mathrm{~km}$ apart. Our samples collected from Iwagasaki resembled E. filamentosus and E. ugoensis in having short laterals and unilocular sporangia, but differed from $A$. crinita in having neither monosporangia nor plurilocular acinetosporangia. In our molecular analyses, the samples from Iwagasaki were placed in the clade of Japanese Acinetospora samples with unilocular sporangia. Therefore, we propose the new combination A. filamentosa as name for the clade. Ectocarpus ugoensis was distinguished from $E$. filamentosus by having spherical unilocular sporangia, which is different from the ellipsoid unilocular sporangia of the latter (Konno and Noda 1974). However, we observed spherical to ellipsoid unilocular sporangia in our $A$. filamentosa culture, suggesting 
that the difference in the shape of sporangia is not appropriate to separate these species. Therefore, we consider $E$. ugoensis as a synonym of $A$. filamentosa.

The majority of field-collected thalli of $A$. filamentosa and $A$. asiatica had no reproductive organs on their erect filaments (Table 1) and were, therefore, difficult to identify based on morphology. Both species were found in Innoshima, Seto Inland Sea and Hakodate, Hokkaido, suggesting that their distributions overlap. In contrast, records of only $A$. filamentosa in Okinawa (southern islands of Japan) suggest that its distribution extends to warmer regions than that of $A$. asiatica. In the previous accounts of A. crinita from Japan (Kurogi 1950, Tanaka and Chihara 1977, Kitayama 1996), plurilocular acinetosporangia/megasporangia and monosporangia were not reported, so that Japanese $A$. crinita likely belonged to A. filamentosa or A. asiatica. Distributions of both species in areas other than Japan are unknown, but a cox1 sequence of "Acinetosporaceae sp." from Greece was identical to that of a Japanese sample of A. filamentosa, suggesting a wider distribution of this species.

Acinetospora was regarded to be so closely related to Feldmannia and Hincksia that Kornmann (1953) and Knoepffler-Péguy (1974) considered A. crinita as a phase in the life history of Feldmannia or Hincksia (as Giffordia) based on their culture studies. In contrast, Amsler and Kapraun (1985) suggested that morphological similarities among these three genera are artefacts of incomplete development and mentioned that they should be retained as separate genera. Kim and Lee (1994) and Pedersen and Kristiansen (2001) clearly defined the three genera, using characters of crampons, meristems and the position of sporangia, against the opinions of Kornmann (1953) and Knoepffler-Péguy (1974). However, in the cox1 analyses of Peters et al. (2015), which included the type species of the three genera [Feldmannia lebelii (Areschoug ex P.L. Crouan et H.M. Crouan) G. Hamel, Hincksia hincksiae (Harvey) P.C. Silva (=Hincksia ramulosa J.E. Gray) and A. crinita], Feldmannia and Hincksia did not separate into distinct clades. Moreover, in our molecular analyses based on $r b c \mathrm{~L}$ and cox 1 sequences, Acinetospora species did not form a single clade; rather, the generated trees suggested that $A$. asiatica is more closely related to Feldmannia irregularis, F. mitchelliae (Harvey) H.-S. Kim and Hincksia sp. than to A. crinita. These molecular results suggest that taxonomic revision of these three genera is required. Although A. asiatica was closely related to Feldmannia spp. and Hincksia sp., this species was distantly related to the type species of Feldmannia and Hincksia, which were positioned in the Pylaiella-Hincksia-Feldmannia (PHF) group in the cox 1 analyses by Peters et al. 
(2015). In addition, A. asiatica was more closely related to the type species of Acinetospora than to the type species of either Feldmannia or Hincksia. As we have indicated earlier, the existing taxonomic problems within Feldmannia, Hincksia and Acinetospora have long been debated, and the need to revise their generic concepts is apparent. Significant progress can be made by conducting further studies on the Acinetosporaceae to settle and clearly delimit the different taxa especially at the generic level. Therefore, at this moment, we attribute A. asiatica to its genus based on morphological features.

Acknowledgments: We thank Prof. Kouichi Ohwada, Prefectural University of Kumamoto for samples from Ashikita, Kumamoto Prefecture. We also thank A.F. Peters for information of his culture strains.

\section{References}

Amsler, C.D. 1984. Culture and field studies of Acinetospora crinita (Carmichael) Sauvageau (Ectocarpaceae, Phaeophyceae) in North Carolina, USA. Phycologia 23: 377-382.

Amsler, C.D. and D.F. Kapraun. 1985. Giffordia onslowensis sp. nov. (Phaeophyceae) from the North Carolina continental shelf and the relationship between Giffordia and Acinetospora. J. Phycol. 21: 94-99.

Bornet, E. 1891. Note sur quelques Ectocarpus. Bull. Soc. Bot. France 38: 353-372.

Cardinal, A. 1964. Étude sur les Ectocarpacées de la Manche. Beih. Nova Hedwigia 15: 1-86, figs 1-41.

Clayton, M.N. 1974. Studies on the development, life history and taxonomy of the Ectocarpales (Phaeophyta) in Southern Australia. Aust. J. Bot. 22: 743-813.

De Toni, G.B. 1895. Sylloge algarum omnium hucusque cognitarum. Vol. III. Fucoideae. Seminarii, Patavii (Padua). pp. 638.

Felsenstein, J. 1985. Confidence limits on phylogenies: an approach using the bootstrap. Evolution 39: 783-791.

Harvey, W.H. 1833. Div. II. Confervoideae; Div. III. Gloiocladeae. In: (W.J. Hooker, eds) The English Flora of Sir James Edward Smith. Class XXIV. Cryptogamia. Vol. V. (or Vol. II of Dr. Hooker's British flora). Part I. Comprising the Mosses, Hepaticae, Lichens, Characeae and Algae. Longman, Brown, Green \& Longmans Paternoster-Row, London. pp. 263-265, 265-266, 326-389, 389-405.

Harvey, W.H. 1841. A manual of the British algae: containing generic and specific descriptions of the known British species of seaweeds and of Confervae both marine and fresh-water. John Van Voorstpp, London. pp. 229.

Hollenberg, G.J. 1971. Phycological notes V. New species of marine algae from California. Phycologia 10: 11-16.

Kim, H.-S. 2010. Ectocarpaceae, Acinetosporaceae, Chordariaceae. In: (H.-S. Kim and S.-M. Boo, eds) Algal flora of Korea. Volume 2, Number 1. Heterokontophyta: Phaeophyceae: Ectocarpales. Marine brown algae I. National Institute of Biological Resources, Incheon. pp. 3-137.
Kim, H.-S. and I.K. Lee. 1994. Morphotaxonomic studies on the Korean Ectocarpaceae (Phaeophyta) III. Genus Feldmannia Hamel, specially referred to morphogenesis and phylogenetic relationship among related genera. Korean J. Phycol. 9: 153-168.

Kitayama, T. 1996. Brown Algae from Onagawa Bay, Miyagi Pref., Japan. Mem. Natn. Sci. Mus. 29: 223-230.

Knoepffler-Péguy, M. 1974. Le genre Acinetospora Bornet 1891 (Phaeophyceae-Ectocarpales). Vie Milieu (A) 24: 43-72.

Kogame, K., T. Horiguchi and M. Masuda. 1999. Phylogeny of the order Scytosiphonales (Phaeophyceae) based on DNA sequences of $r b c \mathrm{~L}$, partial $r b c S$ and partial LSU nrDNA. Phycologia 38: 496-502.

Konno, K. and M. Noda. 1974. On the species of Ectocarpus Lyngbye from the coast of Akita Prefecture facing the Japan Sea. Sci. Rep. Niigata Univ., Ser. D 11: 75-80.

Kornmann, P. 1953. Der Formenkreis von Acinetospora Bornet 1891 (Carm.) nov. comb. Helgol. Wiss. Meeresunters. 4: 205-224.

Kurogi, M. 1950. On the Ectocarpus-complex of Hokkaido. Bot. Mag., Tokyo 63: 233-234.

Lane, C.E., S.C. Lindstrom and G.W. Saunders. 2007. A molecular assessment of northeast Pacific Alaria species (Laminariales, Phaeophyceae) with reference to the utility of DNA barcoding. Mol. Phylogenet. Evol. 44: 634-648.

Müller, D.G. 1986. Apomeiosis in Acinetospora (Phaeophyceae, Ectocarpales). Helgol. Wiss. Meeresunters. 40: 219-224.

Noda, M. 1970. Some Marine Algae collected on the coast of Iwagasaki, Prov. Echigo facing the Japan Sea. Sci. Rep. Niigata Univ., Ser. D 7: 27-35.

Nylander, J.A.A. 2004. MrModeltest v2. Program distributed by the author. Evolutionary Biology Centre, Uppsala University.

Pedersen, P.M. and A. Kristiansen. 2001. On the enigmatic brown alga Acinetospora crinita (Ectocarpales, Fucophyceae). Cryptogam. Algol. 22: 209-218.

Peters, A.F. and M.E. Ramírez. 2001. Molecular phylogeny of small brown algae, with special reference to the systematic position of Caepidium antarcticum (Adenocystaceae, Ectocarpales). Cryptogam. Algol. 22: 187-200.

Peters, A.F., L. Couceiro, K. Tsiamis, F.C. Küpper and M. Valero. 2015. Barcoding of cryptic stages of marine brown algae isolated from incubated substratum reveals high diversity in Acinetosporaceae (Ectocarpales, Phaeophyceae). Cryptogam. Algol. 36: 3-29.

Ronquist, F. and J.P. Huelsenbeck. 2003. MRBAYES 3: Bayesian phylogenetic inference under mixed models. Bioinformatics 19: 1572-1574.

Sauvageau, C. 1895. Note sur 1 'Ectocarpus pusillus Griffiths. Jour. De Bot. 9: 274-287.

Sauvageau, C. 1899. Les Acinetospora et la Sexualité des Tilopteridacées. Jour. De Bot. 13: 107-127.

Siemer, B.L., W.T. Stam, J.L. Olsen and P.M. Pedersen. 1998. Phylogenetic relationships of the brown algal orders Ectocarpales, Chordariales, Dictyosiphonales and Tilopteridales (Fucophyceae) based on RUBISCO large subunit and spacer sequences. J. Phycol. 34: 1038-1048.

Silberfeld, T., M.-F.L.P. Racault, R.L. Fletcher, A. Couloux, F. Rousseau and B. De Reviers. 2011. Systematics and evolutionary history of pyrenoid-bearing taxa in brown algae (Phaeophyceae). Eur. J. Phycol. 46: 361-377.

Tamura, K. and M. Nei. 1993. Estimation of the number of nucleotide substitutions in the control region of mitochondrial DNA in humans and chimpanzees. Mol. Biol. Evol. 10: 512-526. 
Tamura. K., D. Peterson, N. Peterson, G. Stecher, M. Nei and S. Kumar. 2011. MEGA5: molecular evolutionary genetics analysis using maximum likelihood, evolutionary distance, and maximum parsimony methods. Mol. Biol. Evol. 28: 2731-2739.

Tanaka, J. and M. Chihara. 1977. Note on algae in Japan and adjacent waters (1). J. Jpn. Bot. 52: 245-253.

Tatewaki, M. 1966. Formation of a crustaceous sporophyte with unilocular sporangia in Scytosiphon lomentaria. Phycologia 6: 62-66.

Womersley, H.B.S. 1987. The Marine Benthic Flora of Southern Australia. Part II. South Australian Government Printing Division, Adelaide. pp. 484.

Yoshida, T. 1998. Marine Algae of Japan. Uchida Rokakuho Publishing Co., Ltd, Tokyo. pp. 1222. (in Japanese).

\section{Bionotes}

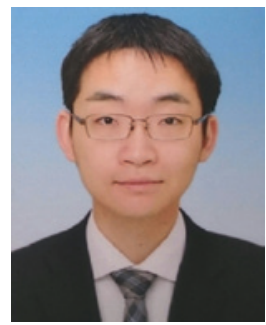

\section{Kousuke Yaegashi}

Department of Natural History Sciences, Graduate School of Science, Hokkaido University, Sapporo 060-0810, Japan

Kousuke Yaegashi earned both his BSc and MSc from Hokkaido University. His master's research was focused on the taxonomy and life history of the Japanese Acinetospora. He now works for a company of chain retailers.

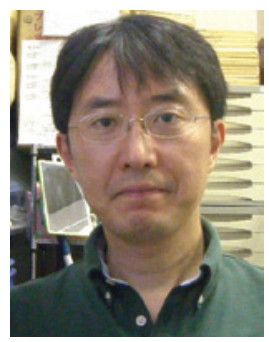

\section{Yukimasa Yamagishi}

Faculty of Life Science and Biotechnology, Fukuyama University, Fukuyama 729-0292, Japan

Yukimasa Yamagishi is a lecturer at the Department of Marine Bioscience, Fukuyama University. He earned his PhD in Biology from Hokkaido University, where he worked on the taxonomy of the red algal genus Hypnea. He has been studying taxonomy and molecular phylogeny of marine red algae.

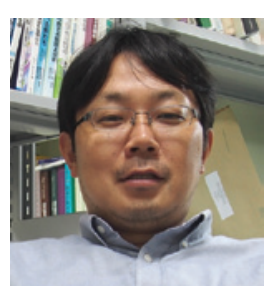

\section{Shinya Uwai}

Faculty of Science, Department of Environmental Science, Niigata University, Niigata 950-2181, Japan

Shinya Uwai is an Associate Professor of Biology in Niigata University. His main study area is seaweed systematics. Recently, he has been interested in speciation processes and invests much effort in studying the genetic and physiological differentiation of conspecific populations of seaweeds, especially those of brown algae.

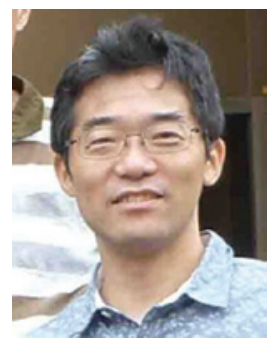

\section{Tsuyoshi Abe}

The Hokkaido University Museum, Hokkaido

University, Sapporo 060-0810, Japan

Tsuyoshi Abe is a lecturer of Phycology at the Hokkaido University Museum, Sapporo. He was awarded a PhD in Biology by Hokkaido University for his work on the biosystematics of the red algal genus Laurencia. His research interests are on the diversity of seaweeds in Japanese waters as well as those from the adjoining waters of Southeast Asia and the Russian Far East. He is also presently conducting chemotaxonomic studies on Laurencia.

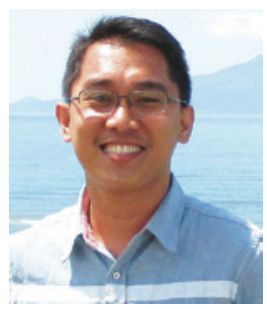

Wilfred John Eria Santiañez

Department of Natural History Sciences, Graduate School of Science, Hokkaido University, Sapporo 060-0810, Japan

Wilfred John Eria Santiañez was formerly a research associate at the Marine Science Institute of the University of the Philippines where he worked on various aspects of seaweed biology, particularly seaweed diversity, ecology, and mariculture. He has a master's degree in Environment and Natural Resource Management from the University of the Philippines Open University and is now pursuing his $\mathrm{PhD}$ in Hokkaido University. His research is presently focused on the diversity and molecular phylogeny of the brown algal genus Hydroclathrus.

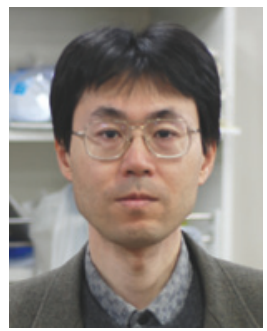

Kazuhiro Kogame

Faculty of Science, Department of Biological Sciences, Hokkaido University, Sapporo 060-0810, Japan, kogame@sci.hokudai.ac.jp

Kazuhiro Kogame is an Associate Professor in the Faculty of Science, Hokkaido University, Japan. His research interests include taxonomy, phylogeny and life history of seaweeds. 